City University of New York (CUNY)

CUNY Academic Works

2020

\title{
Childhood Memories of Playful Antics and Punishable Acts Risking an Imperfect Future of Teaching and Learning
}

Lisa Farley

CUNY York

Debbie Sonu

CUNY Hunter College

Julie Garlen

Carleton

Sandra Chang-Kredl

Concordia

\section{How does access to this work benefit you? Let us know!}

More information about this work at: https://academicworks.cuny.edu/hc_pubs/614

Discover additional works at: https://academicworks.cuny.edu

This work is made publicly available by the City University of New York (CUNY).

Contact: AcademicWorks@cuny.edu 


\title{
Childhood Memories of Playful Antics and Punishable Acts: Risking an Imperfect Future of Teaching and Learning
}

\author{
Lisa Farley, Debbie Sonu, Julie C. Garlen \& Sandra Chang-Kredl
}

To cite this article: Lisa Farley, Debbie Sonu, Julie C. Garlen \& Sandra Chang-Kredl (2020): Childhood Memories of Playful Antics and Punishable Acts: Risking an Imperfect Future of Teaching and Learning, The New Educator

To link to this article: https://doi.org/10.1080/1547688X.2020.1731036

\section{曲 Published online: 03 Mar 2020.}

Submit your article to this journal $\widetilde{x}$

Q View related articles $\sqsubset$

View Crossmark data $\asymp$ 


\title{
Childhood Memories of Playful Antics and Punishable Acts: Risking an Imperfect Future of Teaching and Learning
}

\author{
Lisa Farley ${ }^{a}$, Debbie Sonu ${ }^{b}$, Julie C. Garlenc, and Sandra Chang-Kredl ${ }^{d}$ \\ aYork University, Toronto, Canada; ${ }^{\mathrm{b} C}$ City University of New York, New York, New York, USA; 'Carleton \\ University, Ottawa, Canada; ${ }^{\mathrm{d} C o n c o r d i a ~ U n i v e r s i t y, ~ M o n t r e a l, ~ C a n a d a ~}$
}

\begin{abstract}
This paper takes up the question of risk by examining childhood memories of nuisance-making and punishment shared by 26 participants enrolled in teacher education and/or childhood studies programs. Our analysis surfaces a tension that, on the one hand, idealizes the child as innocent instigator of playful antics and, on the other, produces a child who is guilty of punishable acts. We read these memories as an invitation to theorize a middle ground of the teacher's role as one of introducing children to a world of limits, while also limiting the force of this very effort.
\end{abstract}

In The Beautiful Risk of Education, Gert Biesta (2013) argues that the drive to make education strong and secure has narrowed humanity into a manageable project aimed to eliminate risk. At issue is not simply an aversion to complexity and freedom, but an actuarial response that replaces risk with the promise of fixed futures secured by competitive individualism (Brown, 2019). The drive to narrow risk can be situated in the larger context of neoliberalism that gives near exclusive priority to the free market, rendering the world and all its capaciousness in terms of economic capital. As Cristina Delgado Vintimilla (2014) argues, neoliberalism is a "mode of governance" that works insidiously through everyday practices and expectations to "define and structure the ways in which people conduct themselves" (p. 80). Here, the work of learning is whittled down into "mercantile matter" - made from units of skill, credit, and behaviors - that can be acquired, managed, and measured to maximize efficiencies and achieve predictable outcomes (Vintimilla, 2014, p. 80).

For new educators in what Biesta (2013) calls these "impatient times," there may not be room to pause and slow down, to take risks and to slipup, for overhead looms the warning that there is too much to do and not enough time (p. 3). Risk may feel too risky in a context that measures growth by speed and defines education as a predictive event. In this context, where mastery is the objective and mistakes are construed as weakness, we offer an examination of

CONTACT Lisa Farley Ifarley@edu.yorku.ca $\Theta$ Faculty of Education, York University, 4700 Keele Street, Toronto, ON, M3J1P3, Canada.

(C) 2020 ATE and CCNY 
how adults remember the risky agencies of their own childhoods. Our data is drawn from a larger two-year project that seeks to understand how adult memories of having been children inform ongoing questions, assumptions, and anxieties undergirding contemporary conceptualizations of childhood and education. Our participants are undergraduate students enrolled in teacher education or childhood studies programs across four cities in Canada and the United States. At each of the sites, we invited participants to conjure a formative childhood memory, to visualize the setting and detail, and to write a description of the events and experiences recalled. Participants were then asked to share memories with another colleague and to write a reflective response accounting for the significance of their memory in relation to their aspiring roles as future custodians of the education and well-being of children.

A total of 116 memories were gathered and anonymized. Each of the researchers undertook a preliminary thematic analysis of site-specific data by surfacing recurring motifs and metaphors. We then met as a team to note commonalities and/or differences within the larger data set. At all sites, we found that a majority of the memories centered on experiences that were linked to feelings of happiness and freedom, but also to anxieties, sadness, and struggles across a range of obstacles. While modest in number, the archive of narratives gathered in our study evidences a highly diverse and emotive quality of memory. What "sticks" with any given person is highly variable as is the emotive force of the experiences recalled. However, if memory is emotional, it is certainly not always positive, but also painfully and ambivalently charged.

Across this range of data, we came to wonder about childhood memories that tarry with badness, dabble in failure, break rules, and take seemingly nonsensical actions. We came to think of this data as, in the words of Maggie MacLure (2013), "a cabinet of curiosities" symbolizing excesses of experience that disrupt certitudes (p. 229). Such excesses spill into memories recounting a child's active defiance of or failure to comply with expectations and norms, provoking our "wonder" about the meaning and stakes of risk-taking as children (MacLure, 2013, p. 229). With MacLure (2013), we think of wonder as a disquieting stance of attention in scholarship and scenes of schooling. In wonder, we can be affected by others and objects, at times astonished and at other times anguished, without understanding precisely why. In wonder, we can be compelled in ways that are "recalcitrant and unfit for recruitment to 'proper' social relations" (MacLure, 2013, p. 230). Itself a form of risk, wonder puts us in touch with abject experiences relating to bodies, pleasures, and pains that defy categories of understanding. This sense of wonder frames our attention to the narratives under examination here and is echoed in the plots of the memories themselves; much like us, they trace disruptive affects and effects that detour from pre-set pathways of knowledge and learning. 
In our study, risk takes two trends. The first finds expression in memories representing a child's playful antics or what Adam Phillips (2004), drawing on D.W. Winnicott (1956), calls "nuisance-making." The second trend can be found in memories carrying a traumatic charge, where a child's boundarycrossing is met with punishment and shame. Interestingly, memories constructing risk as playful tend to take place outside the school, while memories of punishment are largely set within classroom settings. At first glance, these two constructions of risk may seem to stand in binary opposition; however, we read both sets of memories as irritants to the neoliberal discourse of learning as "mercantile matter" in that they bring to the foreground stray impulses, breakdowns of meaning, and surprising accidents that learners bump into and at times instigate as they try to embody a sense of self in the world.

For teacher educators, and new educators of children and young people, our study raises questions about what happens when children disturb the order of the school, and in this context, how we might rethink the meaning of the teacher's role. We invite teachers to risk opening, through memory, that "cabinet of curiosities" and so to wonder about the meaning and import of children's disruptive agencies. Against the backdrop of our impatient times, we suggest that the teacher's work involves a delicate balance that means "being less interventionist" (Philo, 2003, p. 8, original emphasis) even as one tries to embody a position of authority. Since teachers do need to introduce children to limits and failures, the question is how they may do so while limiting the force of this often painful demand.

\section{Discourses of risk in education}

In the context of education, risk tends to be framed as a debate about the balance between ensuring children's safety and encouraging their exploration in stimulating environments (Stephenson, 2003). In studying the hazards and benefits of risk, many contemporary studies reframe the tendency to construct risk as a "negative concept that must be avoided or reduced" (Waters $\&$ Begley, 2007, p. 366). These studies rather highlight the value of risky play as a child's right and condition of "healthy development" (Harper, 2017, p. 318). What counts as risky play is, of course, not universal, but highly dependent on culture and context, practitioner judgments, and children's own motivations and understandings (Little, 2006; Sandseter, 2014).

The diagnostic label of "at-risk" constructs children, particularly Black, Indigenous, and Latin@ children, as perpetually in danger, to the point of being forever doomed, or as themselves dangerous and in need of control and punishment (Dumas \& Nelson, 2016; Ferguson, 2001; Meiners, 2016). Prior research in the United States has consistently found disproportionately high incidences of school punishment for children of color, particularly Black boys 
whose suspension rates in elementary school were as high as 12\% (RaffaeleMendez, Knoff, \& Ferron, 2002). Across Canada, too, disproportionate numbers of Black children and youth are suspended and expelled. The construction of innocence endowed to white children does not protect Black children from these forced exits. In Toronto, $14 \%$ of expulsions were handed out to Black elementary school students (Maynard, 2019). Fraught by the afterlife of slavery, residential schools, and the materiality of enduring racism in the United States and Canada, the notion of risk - who is risky and who should be protected from risk - is central to the making of the racialized subject and the discursive formation of both deficit and danger.

If the fabrication of the universal child naturalizes socially constructed discourses that privilege Whiteness, this same figure concocts marginalized children in terms of deficit and collapses social problems into individual failings (Ladson-Billings, 2006, 2007). For racially minoritized children, risk can become pathologized as a "trait" of an individual or group, covering over the larger social conditions and inequities that disadvantage particular children over others. By contrast, "not at risk" children enjoy what has come to be defined as "the rights of children" (Cunningham, as cited in Lohmann \& Mayer, 2009, p. 6) while the highly cultural terms of whose rights are protected and who has access to them go unchallenged.

Despite links to health and development, risky play tends to be cultivated outside of traditional classroom settings, such as playgrounds, "natural landscapes" (Harper, 2017; Maynard \& Waters, 2007, p. 257), and forest schools (Waters \& Begley, 2007). While risky play tends to appear in physical challenges, researchers show how it dovetails with cognitive, social, and emotional processes such as making good judgments, improving concentration, building confidence, overcoming fear, and "seeking out the unknown" (Waters \& Begley, 2007, p. 366). For these reasons, Nevin Harper (2017) argues that it is high time for education to rethink discourses of prevention so prominent in "risk-averse" policies and practices (p. 318). Moreover, Lavrysen et al. (2017) propose that risky play, when supported at school, can lead to a child's development of "risk competence" that involves weighing personal ability against environmental factors (p. 89). As a measure of competence, risky play is not simply reckless - a negative concept to be avoided or reduced - but supports children in the work of distinguishing between productive and unproductive prospects, and in making reasonable choices through this consideration.

While risky play disrupts discourses of control in education, it may nonetheless cultivate a quiet sort of management. In particular, the idea of risk as a competency narrows the uncertainty of risk when it is used to develop behaviors and attitudes that achieve school aims. This last idea mirrors a related discourse of "fun" circulating within early childhood education, where fun is not only a desired quality of educational experience, or the 
measure of a "good day," but a mode of governance that produces expected behaviors, while disavowing the very idea of learning as difficult (Vintimilla, 2014, p. 81). With Vintimilla (2014), we add that the idea of "risk competence," while disrupting constructions of learning as a lock-step or predictable endeavor, may stop short of anything that could be read as too disruptive or uncomfortable. Risk-taking may take an uncritical turn when it is constructed as a competency that is rendered utilitarian to education: a fun link to development and desired outcomes.

Decolonial, queer, and reconceptualist scholars offer another angle of critique that explores the linkages between childhood and natural environments. A growing number of scholars in early childhood education work through a settler-colonial lens to trace how nature is constructed as a neutral place of learning outside of culture, politics, and history (Nxumalo, 2019; Pacini-Ketchabaw \& Taylor, 2015). As Veronica Pacini-Ketchabaw and Affrica Taylor (2015) argue, the meaning and use of nature in early childhood education privileges human-centric ideas that position nonhuman lifeforms as objects of knowledge, rather than as agentic matters that themselves shape and work on what we can know (see also Nxumalo, 2019; Nxumalo \& Stacia, 2017).

Fikile Nxumalo (2019) further exposes the "differential situatedness" of children in place-based early childhood education, noting how nature tends to be deployed "as something that (certain) innocent children need to be returned to, primarily for developmental benefits" (p. 1). However, in alloying childhood with nature, education reproduces "a much larger Western epistemological project" privileging settler-colonial discourses as universal (Pacini-Ketchabaw \& Taylor, 2015, p. 2). These universalizing acts reproduce the figure of the White, settler child as custodian of the future (Nxumalo, 2019), while stamping out the elusive qualities of emotional life (Farley, 2018), the complex materiality of relationships (Pacini-Ketchabaw \& Taylor, 2015), and the highly unequal terms defining who counts as a child, and which children are imagined to have a future (Bernstein, 2011; Nxumalo, 2019).

Across these multiple contexts, risk signifies a range of meanings, including a competency, a developmental achievement, and a symptom of deficit. We add that risk is an ontological condition, marked by the vulnerability of subjectivity as a relational construct. As Sharon Todd (2003) explains, risk lies in our "radical openness" to ambiguity, and in her words, "unknowability" that marks our relationships to each other (p. 68). Against the tendency of education to reduce risk through "rule-governed behaviors, ethical codes, or moral precepts that can be secured through stable significations," Todd (2003), drawing from Emmanuel Levinas, ties risk to our welcome of others and ideas that disrupt the fantasied certitude of pre-given categories, such as "at risk" children or childhood innocence (p. 68). Reminiscent of Biesta, 
Todd (2003) locates the "fine risk" of education in the uncertainty of relationality that opens us to meanings beyond what we already know, exceeding the disciplinary mechanisms of the school (p. 68).

The childhood memories in this study involve incidents, events, and emotions related to nuisance-making and punishments, both of which involve responses to situations in which children take physical, emotional, and cognitive risks. While participants construct acts of school noncompliance in terms of failures and mistakes, non-compliant acts taking place outside of the school are recalled as a rightful claim to freedom, fun, and innocent mischief. In what follows, we present memories that illustrate these two trends. Noting a stark demarcation between memories of nuisance-making and punishment, we query the institutional force of schooling on a child's risky experiments. Almost invariably, the school became the setting for memories of shame, unworthiness, and failure. We also speculate about the significance of race, gender, and class in the dual construction of risk emerging from the data: on the one hand, as innocent nuisance-making and on the other hand, as blame-worthy transgressions. Through our discussion, we encourage teachers to think about the social conditions under which children are afforded risk, to ask when antics are allowed and even encouraged, and to question why and for whom those same actions become punishable acts.

\section{Getting lost, dirty, and messy: On nuisance-making and finding hope}

Mirroring the literature on risk, nuisance-making memories tend to take place outside of school and in the outdoors. Interestingly, these memories made up a minority of the data ( 10 of the 26 examined in this article and of 116 total), itself an observation that suggests an absence of reverie and a pervasive trope of compliance in adult structures of remembering childhood. Between flying down the fireman pole in the schoolyard and tearing through a cornfield, the nuisancemaking memories of this study recall the events leading up to broken bones, the fitful experience of getting lost, and the glee of getting messy and dirty. In these memories, the child is an innocent instigator, one who is in charge of their decisions, but also strangely unwitting in their actions. If any, consequences follow "naturally" in that falling down, or putting your finger in a mousetrap, begets breakage but nothing proportionally worse.

This idea of the innocent instigator also finds its way into nuisance-making memories that, while not literally about breakage, break the boundaries of social norms, often without the child even knowing it. For instance, Bobbie remembers getting undressed during a party attended by parents and friends. Ironically, Bobbie was following too closely her mother's instruction "to take a bath." Before reaching the bathroom, this participant recalls, "I pulled down my pants while these strangers could see me." Bobbie explains her baffling behavior from the perspective of hindsight: "I don't think I understood what was 
embarrassment yet." In this construction, it is possible to do something "socially unacceptable" and escape judgment. In fact, Bobbie suggests that her breach was considered "funny" by the adults surrounding her. Another participant, Jay, also remembers breaking a rule without knowledge or negative consequence. In this memory, the child protagonist is on vacation with family when he decides to walk away - "while [mom and grandmother] were not looking." Far from being a fearful memory, Jay remembers "not knowing I was lost." When asked by two concerned adults where his parents were, Jay continues, "I did not know, nor did I care at the time." When safely reunited with his parents, Jay remembers being given a "balloon."

While Bobbie and Jay's rule-crossing draws the amusement of others, Kate's memory of saying the wrong thing unknowingly makes a painful situation worse. She "distinctly remembers laying on the grass" at her grandfather's funeral. Upon catching a glimpse of her uncle - who she notes "looks exactly like him but a younger version" - she remembers yelling out: "look he's not dead he's still alive." Kate remembers thinking "everyone would be happy to see him," but in actuality, people "started to cry even more." Kate theorizes that, at the time, she "was still too young to understand" death, constructing a child protagonist who is innocent in her instigation.

This theme of not knowing frames another participant's memory of building a rocket ship for two figurine polar bears and suddenly finding herself in the middle of a huge mess. Claire's artistic frenzy with a box of paints goes so far that "the colors began to drown out the brown cardboard until it no longer was." Against the grain of restraint more often associated with schooling and socialization, Claire's memory paints a portrait of the child as an unruly artist, situated in proximity to the impassioned origins of creativity. This messy child figure returns in Alexis's memory of riding in the back of a truck with a goat, playing in an open field, and getting "covered in dirt from the top of my head to my feet." These events draw the playful comments of her uncle who calls her "the dirtiest one here," which, to Alexis, makes perfect sense: "hey I am a child and it only seems right that I'm dirty."

All these childhood antics share a quality of un-intention, linked to cultural tropes of innocence, not knowing, joy, creativity, nature, and animality. Recalled here is an innocent child whose antics and the responses they draw are constructed as harmless and amusing. The innocent instigators of these memories roam liminal spaces outside the school and outside gaze the adults: streets, ledges, playgrounds, and fields. They are the agents of their own development, heroes of their own stories, and breakers of their own bones, while figures of authority are muted. These memories bring to the fore a resilient child who instigates and even enjoys experiences of not knowing, upsetting others, and getting lost without anxiety or fear. In this sense, they repeat tropes of childhood as a carefree time of bliss, even while they toy with risk, boundaries, and injuries. We might even say they are pedagogical in that 
they feature a child who is at work developing "risk competence" in that the antics provide a testing ground between individual capability and outside limits, between freedom and constraint.

Although memories of nuisance-making repeat the common marriage of childhood and innocence, we also speculate that they disrupt this linkage. After all, memories of nuisance-making endow children with a creative and defiant agency. Through them, we encounter a child who crosses rules, messes up "good" behavior, and toys with the fine line between pleasure and pain. Such memories construct childhood not simply as a canvas for adult scripts of development and neoliberal measures of learning, but as actively scribbling outside the lines of predictable outcomes, with little care for the inefficiency of their detours.

In testing social norms, we speculate that such memories reflect what Winnicott (1956) names "the antisocial tendency" (p. 151). Important to our discussion, the antisocial impulse refers neither to a diagnosis, nor any "at-risk" group occupying the margins of society. Rather, the antisocial tendency symbolizes oddball impulses of psychical life carrying emotional significance - and uncertainty. In particular, the antisocial tendency signals the hope for an environment that can receive a child's weightiness of being as they stretch into subjectivity, in the awareness that that embodiment isn't always convenient to others. From the perspective of the antisocial tendency, a child who disobeys the "no", who talks back, and/or who crosses rules is staking a claim on, in Winnicott's (1956) words, "something he has a right to" (p. 150).

If, as studies of risky play suggest, childhood antics reside on the boundary between individual capability and outside constraints, then they may also occupy a painful divide between love and the awareness of loss. "It is as if," thinking with Phillips (2004), "we are involved in a continual love test with the world, trying to find out whether we and it are worth wanting, worth loving" (p. 104). Being a nuisance is an exploration of boundaries between self and other: a way of finding out how much of the self can be tolerated in ways that also test the very commitment of love. In recalling times of nuisance-making - and getting away with it - these memories not only speak out against the constraints of education. They raise questions about the hopeful conditions needed to risk stretching into the fullest extent of one's being. They also raise questions about which children are afforded these conditions. Yet another question is whether schools can be sites of welcome in this effort for all children.

\section{Punishments and the enduring pain of failure}

Strategies for controlling behavior that include rewards and punishments are part of larger disciplinary systems in school. Such accountability practices, strengthened in the risk-averse epoch of neoliberal education, have not only 
led to a slew of popular fads around effective classroom management, but contribute to the discursive construction of children as "risky" beings in the classroom (Katz, 2011). Already conceived of as out of order, children often begin their first weeks of school learning the rules of sociability and the limits of learning, all of which circulate as policies and practices that claim to protect the child and support their development as intelligent, rational, and independent beings.

As Phillips (2013) writes, punishments are based on a set of knowledge as to what adults believe is best for the child and such knowledge is culled and derived from the values of culture, the institution of school, as well as our own experiences and childhood memories. As Phillips (2013) notes, "the way adults deal with these issues is bound up with the history of their own relationship with frustration" (para. 14). Teachers, with their own childhoods, often work through traces of past pains and letdowns when working with students, and at times, can use shame and humiliation to actualize their own sense of significance in the world. While punishing someone can be seen as a break in composure, the teacher who punishes may also be expressing a frustration that comments more on the rules than the students themselves. The pressure to raise achievement, orchestrate an orderly classroom, and resolve conflicts and tantrums are all expectations that the teacher must bear and despite theories on distributive authority, the teacher, at least in these memories, continues to be framed as the sole conductor of a child's institutional socialization.

If memories of antics tend to conjure a child who is free of constraint (Philo, 2003), memories of punishment tend to feature an imposing adult figure who creates for the child a closed spectacle oftentimes within view of others. Audience is a key feature in these memories, illustrating how a larger scene of public judgment carries the power to solidify an emotional charge. Ashley, who falls ill and requests to go to the office, is met by a "frequently irritated and cross" teacher who yells at her "in front of peers to sit up straight." Told to "suck it up," she is made to sit in the hallway "for failure to comply." Hoda, who in the first grade was hit by her teacher for putting shoes on the table, describes this event as "difficult and shameful," feeling that she was then mocked by her peers. Laura, a participant who in the 6th grade who was called "stupid" and told her "brain didn't work normally," describes the consequences of this event as one in which she "lost so many friends, it was embarrassing." These memories, along with others in this category, occur within the distinct pan-optic setting of the school where risk, failure, and pause are quickly cast into a binary split between acceptable or suspect behavior. Here, incidents of discipline are rarely isolated to the student and teacher and carry rippling consequences to other forms of relationships for the child. 
Somewhere along the spectrum of appropriateness and threat, discursive circulations of knowledge communicate to members of the school how the child is to recognize themselves and others in relation to the appropriateness of the setting (Popkewitz \& Brennan, 1998). Therefore, in the context of school, punishments are more than interpersonal; they operate as a "regime of truth" (Foucault, 1977) and recall teaching as a practice of social control rooted in normative judgments that assume particular ways of being in school. Such stabilizations are almost impossible to topple and children must measure the risk of their participation against institutional norms and expectations. Embedded within the theme of risk are threats against making mistakes, falling behind, or disrupting others which operate in symbolic ways and encourage students to manage themselves as risky investments to insecure social and economic futures.

In some memories, a child's public rebuke is linked to their ability to perform expected academic competencies. These included examples such as the pressure of a class math game, coming to school with incomplete homework, or being paralyzed by a writing prompt. The pressure to succeed on assignments and activities incites both an anxious and competitive response from the children. Evee remembers a time when her teacher interrogated her on why she failed a math test, to which she was unable to reply. After repeatedly being asked the same question, she begins to cry and is punished: "I couldn't have my 'snack' a meal we would bring ourselves. I didn't tell my grandma what had happened and just gave the excuse that I wasn't hungry." In this example, Evee sees the withholding of snack as a violation of rightful ownership and she decides to conceal this event from her grandmother. In her narrative, she places quotations around each use of the word "teacher" signaling the un-deservedness of this title as she recalls the incident.

The force of witnessing school punishment led some children to weigh the risk of participating in their own learning. During a math game, Alice recalls, "[The teacher] would start counting ' $1,2,3, \ldots$ ' if it took you long to respond. Sometimes even the other students would start counting ... This memory left me always feeling nervous when calling on me ... to the point I would be scared of [the teacher]." As the playing children are being socialized to close in on the slow individual and enforce the timed expectations of the game, the intense pressure placed on Alice ignites a paralyzing anxiety that grows into an outright fear of the adult under whose care she is left.

The risk of being wrong in the face of others leads to a similar kind of paralysis for Alison who remembers a second-grade writing assignment in which the teacher asked, "what do you want to be when you grow up?" A seemingly innocuous and inventive writing prompt ignites great anxiety for Alison who takes the question literally and, without a sense of her own future, begins to drown. As the other students are writing about their imagined careers, Alison describes her reaction through "fidgeting with my fingers" and "I remember the feeling of knots in my stomach and wanting to vomit the bad feeling out. I began 
to cry." Feeling as if there was something wrong with her, she begins to believe that she would not ever "become something."

Of all her childhood memories, this one was selected by Alison as the most formative in her life. Beyond the problem of linking childhood to the unforeseen future, this memory signals to adults and teachers how the "conceptualization of the child as a potentiality rather than an actuality" (Castaneda, 2002, p. 1) can produce immense pressures. As a figure responsible for actualizing the adult-constructed hopes of tomorrow, this assignment not only pulled Alison out and away from her present reality, but left her unable to even take the risk of imagining her future self. Quite viscerally, she wanted to vomit the assignment out of her body. Incidents of failure are indeed inextricably linked to notions of success. The ease at which Alison's classmates completed the assignment became the barometer against which she measured her frustration, demonstrating that in a competitive culture, failure can be reinforced directly and also by comparison to measures of success both immediate and imagined.

Such forms of discipline are anchored within centuries-old demands of school, and are coupled with the deliberate use of shame, comparison and criticism as sources of motivation. Yet some memories also demonstrate the confused, compliant, or sick child who is disciplined on occasions when they are not in control of the situation. For example, Melissa struggles earnestly to tie her first pair of winter lace-up shoes while the teacher hovers over with impatience. A laborious student who liked to work all the way until the lunch bell, her most visceral memory of school is one of being held responsible for cutting into lunch period. Another example parallels Ashley above: the student who falls ill and is made to sit in the hallway. Gabriella, a sick child who did not want to miss the Carnival Show at school is denied three times to go to the bathroom and ends up vomiting in the classroom. She describes herself as "defeated" by the teacher, and recalls how her startled first grade classmate begins to cry and scream in witness.

As researchers, but also as teachers, we found these memories of school punishment and shame difficult to encounter. Their sheer emotional force reminds us that punishments in school can leave painful residues for decades to come. Memories of punishment, shame, and failure often ended in melancholic notes such as "I will always remember it," "This memory always left me feeling nervous," "It took me three years to overcome," or "It took me a long time." In contrast, memories of antics, which we explore above, tend to refer to episodic and incidental experiences that do not carry lasting consequences. They conjure a child whose defiant actions take place in dreamlike places that are outside the adult's gaze. Given over to their own reveries, this is a child with "nothing troubling his or her thoughts" and who is unencumbered from the "cares and activities of adult life" (Philo, 2003, p. 12). 
In examining memories of punishment, we have come to wonder if such incidences are heightened under the pressure of neoliberal reforms where teaching is valued for its effectiveness to perform on a regime of assessments and exams, scores that get factored into the evaluation of teachers as well as students. The stress placed on teachers to demonstrate a certain level of skills-based performance may be transferred to students in the form of tightened expectations which are cajoled by the use of public shame and punishment. The punishing hand may not be about the child at all, but rather a response to a myriad of conditions that barrel down on the teacher, their desire to protect the child or a sense of inadequacy or loss of control of the profession. Of course, we cannot know if this was the case for the teachers in participants' memories; yet, there may be value in tying incidences of school discipline with contemporary institutional demands for achievement and to query the enduring traces of such demands in the memories of children. While schools are ripe settings for memories of punishment, we may also ask, can memories of nuisance-making invite new educators to make trouble, resist, and re-imagine the meaning and role of the teacher?

\section{Thinking beneath and between play and punishment: Or, risking imperfection}

Childhood memories may tell us something about children's experiences of schooling; but, they may also convey new educators' lingering thoughts, hopes, and anxieties about the pedagogical present and future (Britzman, 1993/2003). Indeed, the new educators of this study made precisely this link between memory and pedagogy. Those recalling memories of punishment tended to articulate a clear aim to work actively against the use of harsh discipline. Through memories of punishment, they grappled not only with the loss of a child's freedom, but also perhaps the loss of love, which seemed to animate a reparative impulse as they imagined themselves as future educators. Those recalling memories of nuisance-making tended to articulate their ongoing commitments to children's freedom. When invoking the role of the teacher, nuisance-making memoirists appealed to the idea of reason: that clear explanations could help kids make more appropriate decisions for themselves. However, their reflections also tended to underemphasize the idea of the adultin-charge, noting instead the natural consequences of a child's explorations gone too far, such as a fall causing a broken bone. In these efforts to temper punishment and preserve freedom (including the freedom implied in a child's use of reason to limit their own impulses), the new educators of this study scratch the surface of a conflict that Britzman (1993/2003) describes as, on the one hand "wanting to become a teacher" and, on the other hand, "not necessarily wanting to step into the role of cruel authority" (p. 4). 
We are hard-pressed to disagree with the desires of our participants to sustain childish playfulness while bringing an end to unjust punishments. In some ways, the nuisance-making child figure may be read as bringing into relief the terrors of authority gone wrong. However, in recalling memories of childhood play and teacher punishment, we detect a split between "good" and "bad" agency, where goodness is attributed to the spirited child and badness to the severe adult. Turning to Alan Prout (2011), we know that dichotomies can defend against the ambiguities of meaning, in that they "exclude all that lies beneath and between them" (p. 8). As Prout argues, dichotomies turn our attention away from childhood as a "complex phenomenon" that is "not readily reducible to one end or the other of a polar separation" (p. 8). One challenge is how to engage the "excluded middle" that comprises the connections, mediations, and mutual dependencies between such extremes (p. 4). In the opposing figures of the pesky child and punitive adult, the memories of this study shine an unexpected light on the excluded middle of authority made from the conflict of affecting others while also being affected in this role. Between memories of play and punishment, the excluded middle may harbor an unpopular prospect: teaching does involve introducing children to a world of limits; teachers must at times say no and/or they must also work through failure, including their own. The implied question between these extremes is how teachers may embody authority in ways that impact others while being open to the meanings of experiences that are not amenable to their influence.

While the project of schooling requires a certain degree of compromise, in that learning requires the subject to "relinquish its own unconscious desires and drives in the service of sociality" (Todd, 2003, p. 19), education need not be reduced to a closed act of socialization that over-determines the experiences of either the student or teacher. This last idea becomes particularly important in school contexts where the pressures to achieve rigid standards can manifest as an overreliance on notions of efficiency. This "hyper-technical disposition" (Dimitriadis, 2012), adopted from economists, disassociates the child from their present condition and converts them into manageable beings subject to fantasies of adult control. A parallel conversion may occur for the teacher as well, who, in this neoliberal context, is charged with not only bringing up the child according to external mandate, but may find themselves faced with little time to imagine education as anything more than scripted curriculum and measure of conformity: an all-too-common effect of schooling that, in the words of Britzman (1993/2003), "diminishes prospects of becoming something other than what has been previously established" (p. 46). Such repressive frameworks seek to remove or tame the nuisance-maker, the creative rebel, or even worse, the bad test taker, adding pressures for teachers, too, who, in order to avoid their own punishments and shame, may, despite their best 
intentions, exercise corrective measures on children as a means to preserve their own value in a context that "privileges routinized behavior over critical action" (Britzman, 1993/2003, p. 46).

If we hold the position that emotional life matters, as do Britzman and A. Freud, then "there is reason to limit the interference" exacted by adults in the name of education and socialization (Britzman, 2010, p. 242). In her lectures to parents and teachers, A. Freud (1936) made precisely this point when she urged her audience to limit the rush to intervene. She advised them to think through the emotional significance of children's messy experiments in becoming that fall outside the adult's prompting or wanting. While these aberrations are often projected onto the idea of the child's "quasi-human" status justifying the need for education (Sonu \& Benson, 2016, p. 230), we suggest that they may be productively reframed as humanity's imperfect condition (Todd, 2016).

Starting with imperfection as our human condition, we may engage the middle ground between playful antics and punishable acts with a renewed theory of education as a delicate practice of finding meaning in the unexpected remainders - that "cabinet of curiosities" - of adult/child relationships. Such residues are hopeful, Todd (2003) tells us: because they "cannot be subsumed into the social order," they allow "for the possibility that subjects will make meaning and learn in unpredictable ways" (Todd, 2003, p. 19). Memories that recall and remind us of a child's naughty acts of disobedience, of freezing up and getting dirty, or of making a mistake and getting it "wrong" do not call for more education; they call for educators to consider the emotional stakes and value of risk-taking in childhood, to consider the consequences of pedagogical interventions, and to consider whether they need to intervene at all. Only through reflection into our role in the making of childhood memory can we read the important news they carry: that risking failure may be the beautiful and painful condition of education and humanity itself.

\section{Disclosure statement}

No potential conflict of interest was reported by the authors.

\section{Funding}

This work was supported by the Social Sciences and Humanities Research Council of Canada [420-2018-0689].

\section{References}

Bernstein, R. (2011). Racial innocence: Performing American childhood from slavery to civil rights. New York, NY: New York University Press.

Biesta, G. (2013). The beautiful risk of education. Boulder, CO: Paradigm Publishers. 
Britzman, D. (1993/2003). Practice makes practice: A critical study of learning to teach. Albany, NY: SUNY.

Britzman, D. (2010). Some psychoanalytic notes on quiet, ordinary and painful resistance. International Journal of Leadership in Education, 13(3), 239-248. doi:10.1080/ 13603124.2010.496874

Brown, W. (2019). In the ruins of neoliberalism: The rise of antidemocratic politics in the west. New York, NY: Columbia University Press.

Castaneda, C. (2002). Figurations. Durham, NC: Duke University Press.

Dimitriadis, G. (2012). Critical dispositions: Evidence and expertise in education. New York, NY: Routledge.

Dumas, M., \& Nelson, J. D. (2016). (Re)imagining black boyhood: Toward a critical framework for educational research. Harvard Educational Review, 86(1), 27-47. doi:10.17763/ 0017-8055.86.1.27

Farley, L. (2018). Childhood beyond pathology: A psychoanalytic study of development and diagnosis. Albany, NY: SUNY.

Ferguson, A. A. (2001). Badboys: Public school in the making of Black masculinity. Ann Arbor, MI: University of Michigan.

Foucault, M. (1977). Discipline and punish: The Birth of the prison. New York, NY: Random House.

Freud, A. (1936). Psycho-analysis for teachers and parents (B. Low, trans.). New York, NY: W. W. Norton.

Harper, N. (2017). Outdoor risky play and healthy child development in the shadow of the 'risk society': A forest and nature school perspective. Child and Youth Services, 38(4), 318-334. doi:10.1080/0145935X.2017.1412825

Katz, C. (2011). Accumulation, excess, childhood: Toward a countertopography of risk and waste. Documents D'anàlisi Geogràfica, 57(1), 47-60.

Ladson-Billings, G. (2006). From the achievement gap to the education debt: Understanding achievement in U.S. schools. Educational Researcher, 35(7), 3-12. doi:10.3102/ 0013189X035007003

Ladson-Billings, G. (2007). Pushing past the achievement gap: An essay on the language of deficit. Journal of Negro Education, 76(3), 316-323.

Lavrysen, A., Bertrands, E., Leyssen, L., Smets, L., Vanderspikken, A., \& De Graef, P. (2017). Risky-play at school. Facilitating risk perception and competence in young children. European Early Childhood Education Research Journal, 25(1), 89-105. doi:10.1080/ 1350293X.2015.1102412

Little, H. (2006). Children's risk-taking behaviour: Implications for early childhood policy and practice. International Journal of Early Years Education, 14(2), 141-154. doi:10.1080/ 09669760600661427

Lohmann, C., \& Mayer, C. (2009). Lessons from the history of education for a 'century of the child at risk'. Paedagogica Historica, 45(1-2), 1-16. doi:10.1080/00309230902746313

MacLure, M. (2013). The wonder of data. Cultural Studies - Critical Methodologies, 13(4), 228-232. doi:10.1177/1532708613487863

Maynard, R. (2019, December 9). Canadian education is steeped in anti-Black racism, The Walrus. Retrieved from https://thewalrus.ca/canadian-education-is-steeped-in-anti-black-racism/

Maynard, T., \& Waters, J. (2007). Learning in the outdoor environment: A missed opportunity? Early Years, 27(3), 255-265. doi:10.1080/09575140701594400

Meiners, E. (2016). For the children? Protecting innocence in a carceral state. Minneapolis, MI: University of Minnesota Press.

Nxumalo, F. (2019). Decolonizing place in early childhood education. New York, NY: Routledge. 
Nxumalo, F., \& Stacia, C. (2017). Decolonizing place in early childhood studies: Thinking with indigenous onto-epistemologies and Black feminist geographies. Global Studies of Childhood, 7(2), 99-112. doi:10.1177/2043610617703831

Pacini-Ketchabaw, V., \& Taylor, A. (2015). Unsettling the colonial places and spaces of early childhood education. New York, NY: Routledge.

Phillips, A. (2004). Nuisance-making. The Threepenny Review, 99(autumn), 9-11.

Phillips, A. (2013). The magical act of a desperate person. London Review of Books, 35(5), 19-20. Retrieved from https://www.lrb.co.uk/v35/n05/adam-phillips/the-magical-act-of -a-desperate-person

Philo, C. (2003). 'To go back up the side hill': Memories, imaginations and reveries of childhood. Children's Geographies, 1(1), 7-23. doi:10.1080/14733280302188

Popkewitz, T., \& Brennan, M. (1998). Restructuring of social and political theory in education: Foucault and a social epistemology of school practices. In T. Popkewitz \& M. Brennan (Eds.), Foucault's challenge: Discourse, knowledge, and power in education (pp. 1-38). New York, NY: Teachers College Press.

Prout, A. (2011). Taking a step away from modernity: Reconsidering the new sociology of childhood. Global Studies of Childhood, 1(1), 4-14. doi:10.2304/gsch.2011.1.1.4

Raffaele-Mendez, L. M., Knoff, H. M., \& Ferron, J. F. (2002). School demographic variables and out-of-school suspension rates: A quantitative and qualitative analysis of a large, ethnically diverse school district. Psychology in the Schools, 39, 259-277. doi:10.1002/pits.10020

Sandseter, H. (2014). Early childhood education and care practitioners' perceptions of children's risky play: Examining personality and gender. Early Child Development and Care, 183(4), 434-449. doi:10.1080/03004430.2013.794797

Sonu, D., \& Benson, J. (2016). The quasi-human child: How normative conceptions of childhood enabled neoliberal school reform in the United States. Curriculum Inquiry, 46 (3), 230-247. doi:10.1080/03626784.2016.1168259

Stephenson, A. (2003). Physical risk-taking: Dangerous or endangered? Early Years, 23(1), 35-43. doi:10.1080/0957514032000045573

Taylor, A. (2015). Reconfiguring the natures of childhood. New York, NY: Routledge.

Todd, S. (2003). Learning from the other: Levinas, psychoanalysis, and ethical possibilities in education. Albany, NY: SUNY.

Todd, S. (2016). Toward an imperfect education: Facing humanity, rethinking cosmopolitan (2nd ed.). New York, NY: Routledge.

Vintimilla, C. (2014). Neoliberal fun and happiness in early childhood education. Children: Journal of the Canadian Association for Young Children, 39(1), 79-87.

Waters, J., \& Begley, S. (2007). Supporting the development of risk-taking behaviours in the early years: An exploratory study. Education 3-13, 35(4), 365-377. doi:10.1080/ 03004270701602632

Winnicott, D. W. (1956). The antisocial tendency. Through paediatrics to psycho-analysis: Collected papers (pp. 47-66). New York, NY: Brunner Routledge. 